\title{
The Lost World of Marshal J: History, Memory, and Iowa's Forgotten Broadcast Legend
}

\author{
PHILLIP J. HuTCHISON
}

AT 4:30 P.M. ON OCTOBER 3, 1954, a lanky Iowa cowboy named Jay Alexander initiated a ritual that would come to shape the daily habits of untold numbers of midwestern families for nearly seven years. Each weekday afternoon, throughout sizable areas in four midwestern states, children rushed home from school, donned western gear, and gathered in front of black-and-white television sets. Meanwhile, parents adjusted rooftop antennas with set-top rotors and ensured that afterschool snacks were in abundance. Then, as strains of "Tumbling Tumbleweeds" spilled out of the sets, young viewers excitedly watched Alexander, a fully adorned 6' 6" cowboy, gallop furiously toward the television camera on his striking golden Palomino. Just as the pair reached the camera, Alexander pulled hard on the horse's reins and skidded to a dusty stop. He then hopped off his mount with dramatic flair, looked directly into the camera and invited the audience to join him in his tack room for an hour's worth of cartoon fun and cowboy banter.

To television viewers across the region, the Cedar Rapidsbased Alexander was no ordinary cowboy: he was Marshal J, one of the era's most prominent personalities - not only in children's television but all local television in eastern Iowa and neighboring states. Several factors underscored his popularity: From 1954 until early 1961, during the heyday of the nationwide

THE ANNALS OF IOWA 68 (Spring 2009). (C) The State Historical Society of Iowa, 2009. 
television cowboy phenomenon, Alexander's cowboy credentials were beyond reproach. He was a bona fide professional cowboy who competed on the rodeo circuit and socialized with western luminaries such as Gene Autry, Roy Rogers, Hopalong Cassidy, and Gabby Hayes.

As a paragon of a television genre that shaped the medium's early years, for more than a decade Alexander entered hundreds of thousands of homes each day via the broadcast airwaves of Iowa and, later, the San Francisco Bay area. In both areas, fans and coworkers recall that Alexander, in his larger-than-life Marshal J persona, not only could ride, rope, and shoot with the best of the television cowboys, but he was also creative and funny and projected a quiet, folksy charm that mesmerized younger and older children alike. Even 50 years later, some of his former fans fondly recall hurrying home from school, changing into western gear, and fighting with older siblings over control of the television when Marshal J aired. They attest to hanging on his every word during the program, because Marshal J was their idol. ${ }^{1}$

Yet despite his one-time intense popularity, and despite representing the subject matter of several Iowa urban legends, in the years following his departure from television nearly all traces of Jay Alexander and Marshal J seem to have disappeared. Alexander is barely mentioned in contemporary histories, unlike many notable Iowa broadcasters, and even his erstwhile employers have been hard pressed to find any artifacts associated with their one-time star. ${ }^{2}$ As is the case with so much of the dis-

1. The accounts were culled from interviews or correspondence with about 50 former fans in Iowa and California. Many of the remarkably consistent accounts use the words idol or hero to describe Alexander. Many grade schools in the region dismissed students at 3:45 p.m., so children had to rush home from school to catch the program after WMT moved it to the 4 p.m. timeslot in 1957.

2. Cary J. Hahn, e-mail message to author, 5/27/2003; Helen Whitson, e-mail message to author, 9/30/2003. A longtime reporter at KGAN-TV, Hahn has served as the station's de facto historian for many projects. Whitson, a now retired broadcast archivist from San Francisco State University, maintained KPIX-TV's archives for many years. Neither could find anything but the sketchiest material regarding Marshal J. Assorted print and broadcast popular histories of Iowa broadcasting include no more than one or two sentences about Marshal J. The most substantial of these popular histories is Jeff Stein, Making Waves: The People and Places of Iowa Broadcasting (Cedar Rapids, 2004). 
posable local TV aesthetic Alexander personified, for assorted reasons much of his history was not documented much less archived. Consequently, existing histories often fail to adequately account for the institutional and social presence of some revealing historical figures and local programming associated with television's early years. $^{3}$

To address such issues as they relate to Iowa history, this article recovers the lost history associated with Jay Alexander. Its first objective is to fill many of the gaps in the historical record associated with Alexander's background and his institutional and social impact in Iowa. The second objective is to address how and why such a highly visible popular culture icon appeared and disappeared from Iowa's social consciousness as Alexander did. Reflecting broader lines of historical research that view early television as a "historical artifact that sheds light on American history and culture," ${ }^{\prime 4}$ Alexander's story informs key social, technological, and economic dynamics as they converged in Iowa during the 1950s. Given the scope of the issues involved, students of Iowa history will benefit from understanding how Alexander realized a vision for his genre in Iowa and beyond, but ultimately proved to be a product of a particular time and set of economic circumstances. His story illustrates how, in many ways, his one-time fame became a casualty of the same prefabricated TV aesthetic he exploited.

On a social level, Alexander's interrelated institutional contributions and his enigmatic presence in the region offer valuable insights into the relationship between local media celebrities and early television audiences. That relationship, as Alexander's story demonstrates, paradoxically was both transient and enduring in ways that, thus far, have not been well documented. Yet as communication scholar James Carey and American Studies scholar George Lipsitz argue, such relationships represent a

3. Tim Hollis, Hi There, Boys and Girls! America's Local Children's TV Programs (Jackson, MS, 2001). Hollis documents this pervasive problem throughout his book. Despite extensive searching, he found very little material about Marshal J.

4. Lynn Spigel, "Our Television Heritage: Television, the Archive, and the Reasons for Preservation," in A Companion to Television, ed. Janet Wasko (London, 2005), 70 . 
revealing facet of collective memory. ${ }^{5}$ About 50 testimonies (oral histories and correspondence) address these factors, highlighting the unexpected ways Jay Alexander's history has been preserved and the ambivalent ways many Iowans remember him. Together, these insights not only illuminate significant issues related to the early years of television in Iowa, but they also shed light on the ways Iowans remember their past and themselves.

MUCH OF ALEXANDER'S LIFE and career, particularly his pre-broadcasting years, is an enigma to those who knew him including his children. Because of his noted storytelling skills, Alexander routinely embellished his biography to fortify his public persona and to obscure the negative repercussions of his decades-long affliction with alcoholism. As a result, and also because so many primary sources have disappeared, today no one seems to know exactly how or why Alexander went into broadcasting, nor has anyone explained exactly what bought him to Iowa. Alexander did provide biographical details to several journalists over the years, but different accounts emerged from each story. ${ }^{6}$

School and military records, however, portray Alexander J. Kotkis Jr., the only child of a noted St. Louis physician and medical school professor, as an unenthusiastic student who loved sports and apparently did not live up to his father's expectations. After dropping out of St. Louis University in 1941, he sold shoes for a brief time before joining the army after World War II broke out. $^{7}$ His military service led to yet another enigma in Alexander's background, a mystery relating to his experiences as a member

5. James W. Carey, "A Cultural Approach to Communication," Communication 2 (1975), 1-22; George Lipsitz, Time Passages: Collective Memory and American Popular Culture (Minneapolis, 1990).

6. Ralph Graczak, “Jay Alexander of St. Louis,” St. Louis Post-Dispatch, ca. 1957. The undated column appeared in an Alexander family scrapbook in the possession of his daughter, Kate Yoemans. It correctly lists Alexander's hometown as St. Louis and acknowledges that his father (who died in 1958) "is" a physician. Elsewhere, Alexander claimed that he grew up on the ranges of Del Rio, Texas, and offered fanciful stories of his childhood there.

7. School records and Kotkis's application, dated, 6/5/1941, for a Social Security account (U.S. Treasury Department Form SS-5). 
of the 66th Division on December 24, 1944. In part because of a decades-long government cover-up of these events, even the master storyteller never discussed his experiences publicly.

On that Christmas Eve, Private Kotkis and 2,234 other members of the 66th Division found themselves crammed into a Belgian troopship, the S.S. Leopoldville, as part of a frantic effort to augment struggling Allied forces during the Battle of the Bulge. However, the Leopoldville never completed its trip across the English Channel that night; it fell prey to a Nazi U-boat's torpedo five miles off the French coast. Although the troopship would not sink into the ink-black channel waters for nearly two hours, numerous accounts have documented the tragically botched rescue operation, a debacle that resulted in the largely avoidable deaths of 765 soldiers from the 66th Division. ${ }^{8}$ How Kotkis escaped the epic carnage has been lost to history; he may have survived a perilous two-story leap to a bobbing and weaving British destroyer - a risky action that claimed numerous lives - or he could have been one of several hundred soldiers plucked from the icy channel waters by late-arriving rescue boats. In either case, the U.S., British, and Belgian governments classified details of the debacle for decades and ordered survivors not to discuss their experiences. ${ }^{9}$ Survivors from the decimated division, including Kotkis, were re-equipped and immediately redeployed into 100 days of close-range combat in the French province of Brittany. Alexander apparently followed orders and never publicly discussed the S.S. Leopoldville disaster, so the longterm impact of the event on his life and career is impossible to gauge in retrospect. ${ }^{10}$

8. Allan Andrade, S.S. Leopoldville Disaster, December 24, 1944 (New York, 1997); The History Channel, "Cover-Up: The Sinking of the S. S. Leopoldville," in History Undercover, DVD (1998).

9. Accounts of the carnage were not made public until 1963, long after Kotkis had legally changed his name to Jay Alexander. The issue was not completely declassified until more than a decade after Alexander's death.

10. Kate Yoemans, e-mail message to author, 3/13/2004. Yoemans is Alexander's daughter. The consequences of war for many World War II veterans are documented in many sources. See, for example, Charles Whiting, Hero: The Life and Death of Audie Murphy (Chelsea, MI, 1990). The story of Audie Murphy, America's most decorated World War II veteran, addresses the scope of the problem. In ways that were not addressed at the time, Murphy, and untold others, became dependent on various substances as a result of war trauma. 
Immediately after the war, Alexander, like millions of fellow veterans, sought his own form of normalcy. During that period, to the extent that his activities can be reconstructed from government records and sketchy family accounts, he briefly returned to college and later married. He also continued to pursue his deep-seated love of sports and horses, a love that resulted in what he described as a one-game stint with the Chicago Cardinals of the National Football League and more extended forays into the rodeo circuit. ${ }^{11}$ When injuries ended those aspirations in about 1950, Alexander turned to sportscasting at small radio stations in Missouri as a way to stay close to sports and provide for his new family.

THE EARLY 1950s proved to be an exciting and challenging time for broadcasters. Taking advantage of the situation, Kotkis adopted a new air name - Jay Alexander - and positioned himself in the middle of the action. At that time, many radio stations were restructuring operations to address changing demographics, evolving tastes, and the growing impact of television. After the Federal Communications Commission (FCC) lifted a nearly four-year television station licensing moratorium in 1952, local television stations rapidly emerged across the nation. ${ }^{12}$

In 1953 Alexander and his young family moved from Hannibal, Missouri, to Cedar Rapids, Iowa, to take a sportscasting position at KPIG Radio (now KMRY), only to lose the job when the station changed its format. ${ }^{13}$ Across town, however, the new medium of television was beckoning. With the lifting of the FCC moratorium, two Cedar Rapids television stations were slated to go on the air in fall 1953. Alexander secured a job as a booth announcer with KCRI-TV (later KCRG-TV), the new ABC affiliate in the area. It was not long before the lanky broadcaster with the

\section{San Francisco Examiner, 11/8/1978.}

12. For an example of the competition that sometimes ensued in the wake of the lifting of the licensing moratorium, see David F. McCartney and Grant Price, "The Battle for Channel 7: A Media Showdown in Waterloo," Annals of Iowa 59 (2000), 261-96.

13. San Francisco Examiner, 11/8/1978; Rick Sampson, e-mail message to author, 4/4/2005. Sampson, a veteran Iowa radio personality and journalist, lived next door to Alexander in the mid-1950s. 
engaging demeanor caught the attention of a program director across town at WMT-TV, the new CBS affiliate, which eventually resulted in a promising new career opportunity for Alexander.

During an era when audiences would stare in fascination at almost anything that appeared via the magic of a cathode ray tube, early television broadcasters faced the dual challenges of filling air time and cultivating new audiences. The moment a local station went on the air, its programmers encountered a voracious medium for which little prepackaged programming existed. Out of necessity, the newer local stations followed precedents established by those local stations that had been licensed before the 1948 FCC licensing moratorium went into effect. During the moratorium period, the initial local stations developed assorted hosted format genres to fill air time, often by modifying established radio strategies. For example, news programming, talk formats, hosted children's programs, and situation comedies all trace their lineage to radio. The initial challenge for early television broadcasters was modifying the formats to accommodate television's visual qualities. Eventually, what worked in one local market was adapted in others. By the mid-1950s, standardized hosted programming genres had become pervasive across the nation. Perhaps the most ubiquitous, popular, and best-remembered artifact to emerge from these circumstances was the locally hosted children's show genre that dominated local airwaves from the early 1950s until the early 1970s.

Although children's shows came in various in-studio formats, including puppet shows, circuses, comedian hosts, and various thematic hosts, only a few could fill their airtime (which ranged from 15 minutes to more than an hour) with purely local entertainment. Thus, the key to success for most early local programs was finding pre-packaged material to accommodate the visual nature of the new medium. At that time, when major motion picture studios were hesitant to release their top quality theatrical cartoon shorts to the new medium, television programmers found a wealth of material in "shoot "em up" Grade B western serials of the 1930s and 1940s. ${ }^{14}$ As a result, in the early 1950s, western-themed children's shows became a staple of local

14. Hollis, Hi There, 6. Eventually, film studios realized that television was the most profitable venue for their cartoon shorts. 
programming across the nation. Further, as television historian Tim Hollis notes, "Realizing that the best way to present films would be by breaking them up with a live host, the most common solution was to put one of the station announcers in a cowboy suit and give him an appropriately rustic setting (western accent optional)." ${ }^{15}$

Given this situation, programmers at WMT-TV noticed the obvious: Alexander, an authentic rodeo cowboy with an abundance of on-air skills, was a natural choice for such a strategy. Thus, in September 1954, WMT hired Alexander as a westernthemed children's show host and weathercaster. In an interview at age 100, WMT's then general manager William B. Quarton recalled the indirect way he found out about that decision. "The first time I became aware of Jay Alexander - Marshal J was when I was visiting with Doug [Grant] at the [Broadcast] Park and all of a sudden a guy on a horse came charging down by the window - like he was going to crash right through it and I said, 'What the hell is that?' Doug replied, 'We hired a cowboy ... and we're making a promotion piece." ${ }^{16}$

The promotion turned out to be for a new daily children's show, The Marshal J Show. The program debuted on October 3, 1954. The charismatic Alexander proved to be a rapid success at both of his new positions. A reputed master of the ad lib, Alexander tailored both jobs around his soft-spoken homespun charm. ${ }^{17}$ Each weeknight on both the 6 and 10 p.m. newscasts, he engaged Iowa's weather-conscious farm communities with his readings of wire-service weather reports. ${ }^{18}$ While popular among adults for his 10 p.m. weather reports from atop a simu-

\section{Ibid.}

16. William J. Quarton, telephone interview with author and Cary J. Hahn, 6/30/2003. Because of Quarton's age, Hahn assisted with the telephone interview and was so delighted with the anecdote that he later met with Quarton to videotape it and include it in the station's fiftieth anniversary special.

17. Jack Voorhies, e-mail message to author and William Hufford, 7/12/2005. Voorhies, a floor director at WMT in the 1950s, directed many of Alexander's programs.

18. William Hufford, e-mail message to author, 11/18/2006; Sampson, e-mail. Hufford, whose well-remembered air name was Ford Roberts, was a noted Iowa broadcaster for more than three decades; he worked at WMT from its inception in 1953 until the mid-1960s. 
lated weather tower, Alexander delivered an even bigger hit with his children's show, a program that was shaped around Alexander's personal vision and his love for children. ${ }^{19}$

During that era, nearly every local television station in the nation - including those in Iowa - offered a hosted program to captivate children with cartoons and, more important for the stations' financial success, targeted advertising. In most cases, particularly in the smaller markets, these programs featured thematic hosts such as sea captains, space travelers, police officers, or cowboys. Usually the hosts were affable but amateurish, and the studio sets were of notoriously slapdash quality. From the outset Alexander articulated a different vision of the genre: In contrast to the syrupy, caricatured "Hi there, boys and girls!" approach to children's shows that he derided throughout his career, Alexander developed the show around three fundamentals: family appeal, education, and attention to detail. ${ }^{20}$

As a central feature of his daily program, Alexander worked hard to convince his audience that he was, in fact, a real cowboy and that everything on his studio tack room set, from the stirrups to the saddles to the branding irons, was real. Between film segments, Alexander amused young viewers with his rope tricks and his cowboy lingo. Each day, in what he described as an ad libbed format, he told compelling stories about the lore of the Old West and taught his young viewers about ranch and outdoor-related skills, such as taking care of animals, camping, firearm safety, and how to use particular tools. Equally notable, the real-life scoutmaster offered children value-laden advice about setting priorities and dealing with others. "I'd talk about a lot of things I guess parents would be talking to kids about but coming from this guy on television maybe it would have more impact," he recounted in $1978 .^{21}$

Noted Iowa broadcaster William Hufford (better known by his air name, Ford Roberts), who during his long career worked with Alexander for several years at WMT and who also worked

19. San Francisco Examiner, 11/8/1978.

20. John Stanley, "The Marshal from Del Rio Is Back in the Saddle at KGO," San Francisco Chronicle, 1964. Alexander explains his views about such issues in this undated article, which was preserved in an Alexander family scrapbook.

21. San Francisco Examiner, 11/8/1978. 


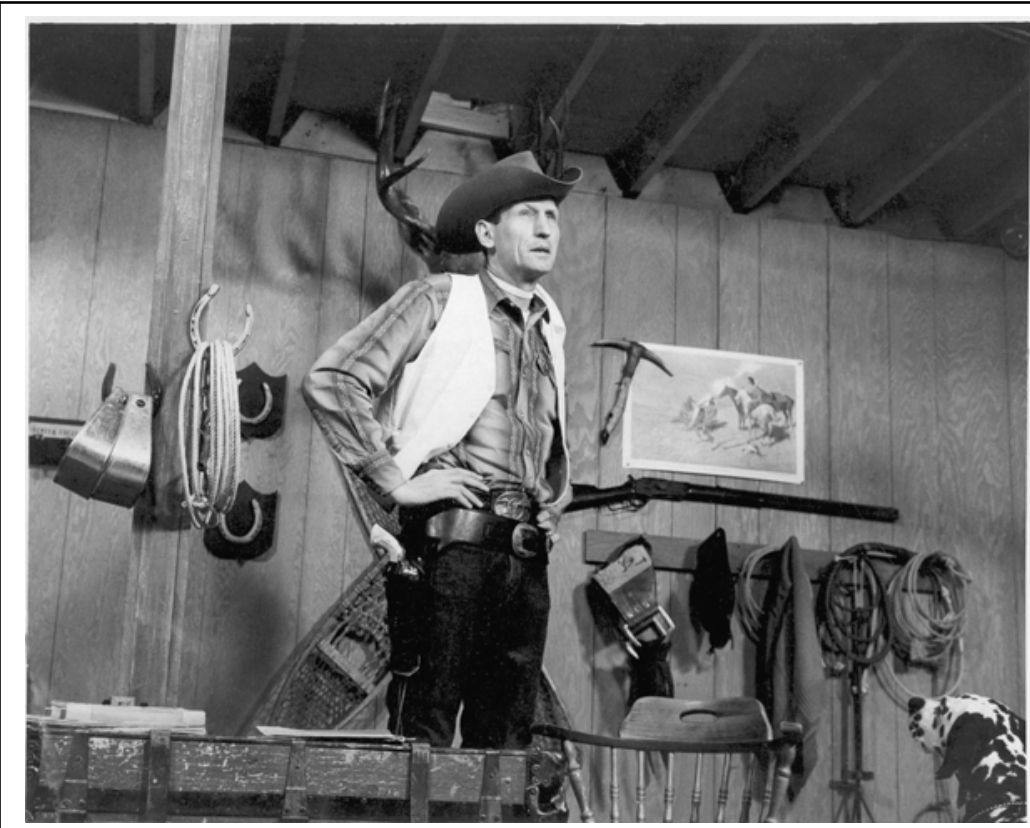

All of the items displayed in the tack room set were authentic. Photo courtesy of Kate Yoemans.

with other Iowa children's show hosts, including Iowa broadcast legend Walt Reno and Des Moines's venerable Duane Ellett (The Floppy Show), explained that Alexander's authenticity and commitment to his character set him apart from his peers.

Jay's talent and his passion for his young viewers was unequalled. ... He was so much more than the usual TV personality. Many of those who worked the kid show market did so as on a lark; it was funny to them, not the real thing. Jay lived the part. As I watched them [other children's show hosts] prepare to go on air they usually had the giggles - kind of a "Hey, look ain't I funny?" Jay did not. He was a natural and above that sort of thing. ${ }^{22}$

AS THE 1950s PROGRESSED, the prevalence of western serials fueled a growing national infatuation with cowboys, a craze that shaped the fashion, toy, and entertainment industries for a

22. Hufford, correspondence. 
decade. ${ }^{23}$ Capitalizing on the trend, Alexander turned his daily television program into a regional happening. Former viewers portray a consistent picture of the late afternoon ritual he presided over for more than six years. After a filmed opening of him galloping up to his tack room, the scene would then seamlessly cut to a live shot of the tack room set and Alexander would lope into view. Fans recall that Alexander filled his program with colorful stories (which unbeknownst to the viewers were fictitious) about his upbringing in the south Texas borderlands. To enhance the effect, he interjected Spanish phrases into his accounts, often referring to his viewers as vaqueros. ${ }^{24}$

The speed and intensity of Alexander's success were remarkable. Grant Price, a longstanding WMT broadcaster whose association with Alexander dates to their days in radio, observes, "He rocketed to prominence doing that cowboy thing. . . . He really lived the part and the kids absolutely worshiped him." ${ }^{25}$ By mid-1955, The Marshal J Show was the centerpiece of WMTTV's afternoon lineup, and Alexander had established himself as one of the premier broadcast stars in his region. ${ }^{26}$

During television's first decade, the limited reception capabilities of early television receivers - particularly in a non-urban region such as eastern Iowa - required the use of rooftop antennas, which were quite effective at accessing distant signals. This factor, when combined with WMT's unusually powerful 100,000watt signal, allowed the station and some of its performers to dominate overlapping television markets that reached across the state of Iowa and well into portions of Minnesota, Wisconsin, and Illinois. ${ }^{27}$ As steadily growing regional audiences tuned

23. Hollis, Hi There; Karal Ann Marling, As Seen on TV: The Visual Culture of Everyday Life in the 1950s (Cambridge, MA, 1994).

24. Alas, no recordings of Marshal J's WMT-TV broadcasts are known to exist.

25. Grant Price, telephone interview with author, 2/11/2008. Price also is noted for establishing the Archives of Iowa Broadcasting at Wartburg College.

26. WMT 600: Radio News from the Voice of Iowa, August 1955, 1.

27. Hufford, e-mail message. Licensed as a multimarket station, WMT went on the air at its full signal strength of 100,000 watts - unlike the reduced-power trial periods competitors often faced. The station's designation as Channel 2, the lowest allocation in the broadcast spectrum, enabled the signal to reach well beyond its standard 80-mile primary range - in extreme circumstances reaching the Rocky Mountain region. When combined with the prevalence of 
into The Marshal J Show, Alexander received invitations for an assortment of increasingly lucrative public appearances. Unlike his competitors, who almost invariably distinguished their onair personas from their personal life, Alexander essentially lived his Marshal J persona as part of the eastern Iowa social milieu. ${ }^{28}$

For his promotional appearances across the region, Alexander developed a repertoire of cowboy acts, ranging from storytelling to demonstrating rodeo skills. Over time, he purchased and trained seven horses, most of which supported his many public appearances. With a custom horse trailer in tow, his regular performances as "Iowa's Cowboy Extraordinaire" became a mainstay at regional rodeos, the Iowa State Fair, county fairs, concerts, and parades, where he occasionally appeared alongside touring western stars such as Gene Autry, Roy Rogers, and Hopalong Cassidy. Photographs of such side-by-side appearances indicate the extent to which the larger-than-life local cowboy towered over the famous stars of western serials. Further, Alexander demonstrated an impressive array of roping and riding skills that, as some fans remember, made it clear who was the more authentic cowboy. ${ }^{29}$

During one such promotional tour in the mid-1950s, Alexander formed a relationship with western legend Gabby Hayes, who earlier had hosted a popular network western-themed children's show. An influential television pioneer, Hayes also served as an informal professional advisor to another emerging

rooftop and tower antennas, these factors created overlapping markets that allowed Marshal J to compete with - and often dominate - outlying broadcast markets served by local stations in Des Moines, the Quad Cities, Rochester (Minnesota), and Madison (Wisconsin). It should be noted, however, that in outlying areas, signal strength influenced viewing habits as much as program quality did.

28. Sampson, e-mail message. As longtime Iowa broadcaster (and Alexander's former neighbor) Sampson explains, Alexander was essentially the kind, charismatic figure he portrayed on television. Furthermore, although Alexander did not initially present himself as a cowboy when he moved to Cedar Rapids, as his phenomenon grew, he changed his wardrobe, his biography, and eventually even his family's name. Over time he bought a farm/ranch near Walker, Iowa, raised horses, and rarely appeared in public out of his trademark attire.

29. Multiple sources, such as photographs and recollections in interviews and correspondence, document Alexander's impressive skills, his imposing presence, and his general lack of "Hollywood" artificiality. 


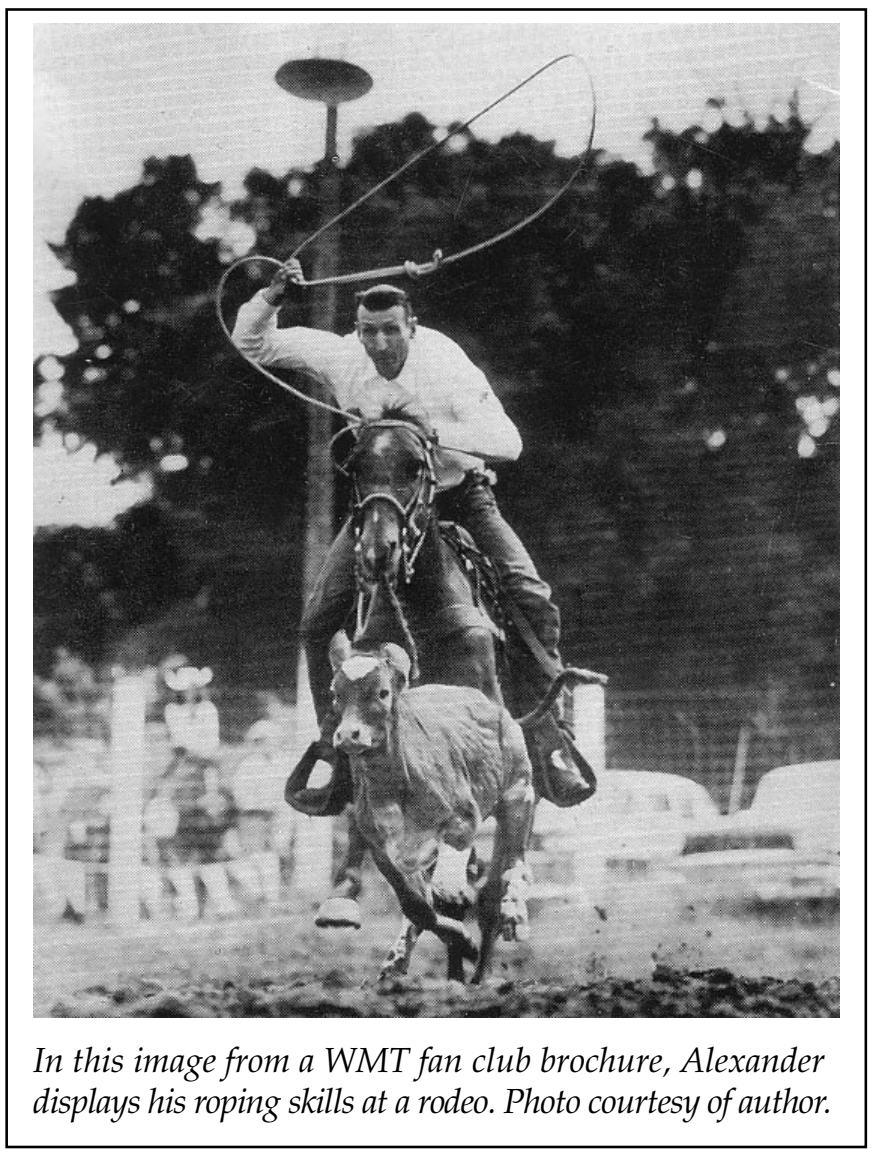

children's show host, Fred Rogers. In both cases, Hayes counseled the up-and-coming children's show hosts that a key to success with the new medium was exploiting its sense of intimacy. Hayes explained that he accomplished this in part by looking into the camera and talking directly to "one little buckaroo out in the audience." ${ }^{\prime 0}$ The "buckaroos" became "neighbors" to Mister Rogers and "vaqueros" to Marshal J, but the approach Hayes recommended set both emergent children's

30. Fred Rogers: America's Favorite Neighbor, PBS documentary directed by Rick Sebak, 2004. In this documentary, Rogers specifically discussed Hayes's advice and how it influenced his subsequent career. Alexander's daughter, Kate Yoemans, in e-mail message to author, 3/13/2004, as well as photographs and other anecdotes, document the relationship between Hayes and Alexander. 


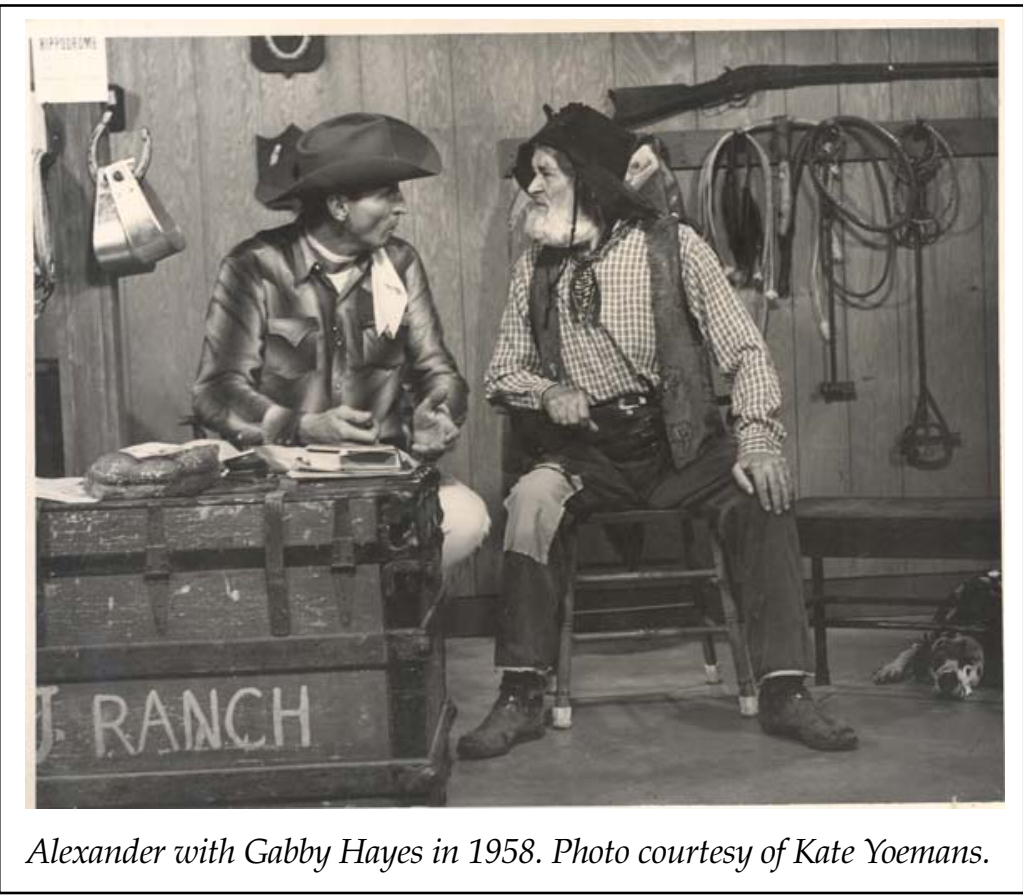

show hosts apart from many of their competitors. Rogers, Alexander, and a handful of others played themselves rather than caricatures; moreover, they talked "to" not "at" their young viewers. Such hosts eschewed in-studio "peanut galleries" and, instead, addressed each individual viewer directly through personal appeals to the camera. They packaged their reassuring messages with soothing voices and nonjudgmental tones. Alexander outlined his philosophy on these matters in a 1964 newspaper interview in response to a question about why he shunned peanut galleries:

There is nothing glamorous about a TV studio. Little people have their own imaginations and dream worlds, and if you bring them in here they would be disillusioned at the sight of all the cables and cameras. . . . We should give them more credit: they have a level of intelligence all their own. I try to reach that level without preaching or whining or acting like a boob. The secret is to teach but entertain at the same time. 
Unlike Rogers, who aligned himself with noncommercial public television beginning in 1954, Alexander embraced commercialism, targeted older children rather than preschoolers, and strapped a real .45 caliber pistol to his hip. ${ }^{32}$ A 60-year-old woman who once counted herself as one of Marshal J's vaqueros, explains, "By today's terms, Marshal J was co-o-o-o-ol."

Noted for his robust approach to life, Alexander's zeal occasionally took forms that were not in his best interests. For example, when he and Gabby Hayes briefly ended up in jail in East Dubuque, Illinois, for staging a gunfight (with blanks) in the main street while both were intoxicated, WMT station manager Doug Grant had to intervene to convince East Dubuque officials that no harm had occurred. ${ }^{34}$ Such incidents represented an enduring problem for Alexander and a major source of frustration for Grant and other WMT officials. The basic problem was fairly straightforward: at some point after the war Alexander became an alcoholic, and alcohol and live television broadcasting - particularly children's shows — did not mix. ${ }^{35}$

During his tenure at WMT, some of Alexander's personal struggles played out over eastern Iowa's airwaves, a factor that

32. One of the most controversial aspects of the genre, a factor that eventually contributed to its demise, involved the standard practice of using the host to pitch products live to an audience of children. Alexander, a master of this skill, pitched everything from breakfast cereal to dairy products on his program.

33. Sampson received this e-mail account from a listener who responded to an on-air query designed to support this research project.

34. Hufford remembers the incident, which, because of Grant's efforts, was not picked up in local newspapers. Colby Bowers, telephone interview with author, $4 / 25 / 2005$. Bowers, a Dubuque native, remembers that even as this and other incidents were not covered in the media, accounts quickly circulated through informal gossip channels throughout the area.

35. The relationship between Alexander's alcoholism and his war experiences remains a mystery. However, both S.S. Leopoldville survivors and historians acknowledge that many survivors were plagued with symptoms of posttraumatic stress disorder, including substance abuse. Yoemans, e-mail message; Hank Anderson, telephone interview with author, 6/24/2003; Allan Andrade, e-mail message to author, 9/29/2005; Ray Roberts, e-mail message to author, 6/11/2003. Anderson, a S. S. Leopoldville survivor, experienced a religious epiphany that night and became a Presbyterian minister as a result. Andrade and Roberts both have published books on the disaster and have interviewed numerous survivors, many of whom are now deceased. Allan Andrade, S.S. Leopoldville, December 24, 1944 (New York, 1997); Ray Roberts, The Leopoldville Trilogy (2001). 
has shaped the way Alexander has been remembered ever since. At least twice, the effects of alcohol undermined Alexander's on-air performance at WMT, each time resulting in punitive action by the station. In August 1955 the effects of alcohol caused Alexander to become tongue-tied to the point of unintelligibility while delivering the weather report on the 10 p.m. news. The incident permanently ended his career as a weathercaster. In about 1960, during The Marshal J Show, Alexander grimaced into the close-up camera while tasting a sponsor's cereal; later he was unable to complete a demonstration on how to string a bow-and-arrow set.

As was the case with the Gabby Hayes incident, the effects of alcohol also occasionally undermined Alexander's public appearances. The most well-remembered example, one that has been the subject of urban legends, occurred in August 1958 during a performance in Dysart, Iowa. That day, Alexander performed a popular part of his act in which he shot at floating helium balloons with a .45 caliber revolver that was modified to fire birdshot. During the demonstration, as one balloon drifted to the ground, he carelessly reholstered his pistol and shot himself in the leg in front of hundreds of spectators. ${ }^{37}$

Yet even as Alexander's drinking problems caused numerous headaches for WMT officials, those who knew him personally recount that he was so well liked by his coworkers and so adored by his fans that station management went to great lengths to avoid firing him. ${ }^{38}$ Thus, management sometimes looked the other way; other times it tried suspensions. More than once Marshal J unexpectedly "went on vacation" or was replaced by "Cousin" Don Hastings while the marshal "helped a friend who broke his leg on a cattle drive." Each time Marshal

\footnotetext{
36. Hufford, who was providing the sportscast the night of the botched weathercast, said that Alexander acted normally before he went on the air, but the heat of the lights apparently brought out the effects of the alcohol. As his weathercast progressed, his speech became increasingly slurred. Several sources witnessed the television show incident both in the studio and over the air.

37. Cedar Rapids Gazette, 8/5/1958.

38. Terry Hull, e-mail message to author, $4 / 27 / 2005$. Hull, a close family friend of the Alexanders in Iowa, explained the situation. Hufford and Sampson confirmed the account.
} 
J disappeared, however, the station was deluged with complaints from Alexander's growing legion of fans. ${ }^{3}$

Ultimately, the star of WMT-TV's late afternoon programming delivered so much to the station and its sponsors that they generally kept the drinking controversies at bay. This was particularly true beginning in 1957, when, because of cultural and industry trends, Alexander's popularity exceeded anything the market had experienced previously. In 1957 and 1958 major motion picture studios finally released their top-line cartoons and theatrical shorts (most notably Popeye, Bugs Bunny, and The Three Stooges) for television broadcast. WMT, as the dominant station in its regional market, quickly obtained the rights for this premier programming and highlighted it on Marshal J's afternoon program. The new programming, by moving away from western serials to cartoons, significantly broadened the cowboy star's appeal to younger children. These factors, along with the station's new 2,000-foot broadcast tower, which dwarfed the competition's 800-foot towers, enabled WMT and Marshal J to dominate regional television markets. As a result, Alexander caught the attention of industry pundits outside of the Midwest. In late 1957 a national television fan magazine highlighted Alexander with a photo spread and biographical article that emphasized his popularity and authentic cowboy persona:

His greeting of "Buenos tardes vaqueros" signals the start of another assignment of hard-riding, fast-shooting excitement with western films and special movie, rodeo and working cowboy guests.... And it is no mere television cowboy doing the talking. Jay spent his boyhood on a Texas cattle ranch learning cowboying as a business. ... And out back of the WMT studios are twenty acres across which cameras can follow Jay and his horses - while his deputies watch from their own particular "ranch houses." ${ }^{40}$

Alexander's rising popularity coincided with America's growing infatuation with television westerns. By autumn 1958, network television had outgrown its roots in Grade B western serials and was featuring 24 adult primetime westerns each week, including seven of the top ten programs in the Nielsen

39. Hufford and Sampson e-mail messages.

40. “Tall in the Saddle," TV Radio Mirror, November 1957, 10. 
ratings. ${ }^{41}$ With fifty million Americans tuning into network westerns each night, the already popular Marshal J had become a highly marketable commodity in major television markets across the nation. WMT management became increasingly aware of their cowboy star's marketability, and they began to share Alexander's vision of expanding his variant of the children's show genre to bigger markets across the nation. WMT filmed a series of Marshal J's programs and marketed them as a syndication proposal, but without success. ${ }^{42}$

BY 1960, Alexander sought to personally capitalize on his vision and take it beyond the eastern Iowa market. Late that year, KPIX-TV, the CBS affiliate in San Francisco, offered Alexander a position that represented a significant increase in salary and proximity to broadcasting's network production facilities in California. Alexander told Doug Grant, WMT-TV's station manager, that he planned to accept the offer. Grant later explained to his son David why the station did not fight to keep its star:

As a matter of fact the salary they paid at WMT-TV was not that much. ... In the TV business and in a minor market like Cedar Rapids-Waterloo, the management had to get used to the idea that many talented people would eventually get better jobs and leave. We were like the minor leagues of television. ${ }^{43}$

Thus, in mid-January 1961 Alexander bid his young viewers a final "hasta luego vaqueros" and moved his program to California. Although many former fans remember feeling traumatized by this sudden development, the prefabricated nature of the genre ensured that WMT suffered little from Alexander's departure. Within two weeks, Grant recruited local amateur actor Max Hahn to replace Alexander as host of the daily children's show. The WMT staff then worked with Hahn to create the role

41. Michael T. Marsden and Jack Nachbar, "The Modern Popular Western: Radio, Television, Film and Print," in A Literary History of the American West (Fort Worth, TX, 1987), 1267.

42. Rick Plummer, e-mail message to author, 9/23/2004.

43. David Grant, e-mail message to author and Rick Plummer, 9/29/2003. David Grant worked on WMT-TV's floor crew and managed the thriving official Marshal J Fan Club. 
of the avuncular "Dr. Max" to maintain the genre's thematic structure. Although many Marshal J fans still are quick to voice their opinions that Dr. Max was inferior to Marshal J in nearly every respect, the not-so-exacting genre proved to be very accommodating of the change. Hahn seamlessly transitioned into the host's role by maintaining Alexander's conversational format and his premier cartoon rotation. ${ }^{44}$ Thus, even as The Dr. Max Show may have been far less compelling than what Marshal J offered, the staid Cedar Rapids-Waterloo television market nicely supported the program for 20 more years, and it overwrote many memories of Marshal J with memories of Dr. Max.

For Alexander, moving an intact children's show format to a larger market represented a major career risk. ${ }^{45}$ Unlike in Iowa, in San Francisco Alexander faced stiff competition from a bevy of established children's show hosts, some of whom achieved legendary status. ${ }^{46}$ Unfazed, on February 13, 1961, at 6:30 p.m., Alexander looked into KPIX-TV cameras for the first time and then turned on the charm that he had cultivated so carefully in Iowa. That evening he enchanted his young viewers by introducing them not only to himself and his fictitious Running J Ranch, but he also introduced a 3-month-old Dalmatian puppy named Rowdy - Marshal J's trademark companion from then on. ${ }^{47}$

44. "Remembering Dr. Max and Mombo," video directed by Cary J. Hahn, 1996. As Max Hahn (no relation to Cary J. Hahn) explained in a 1981 interview that was included in this video tribute to his program, after Alexander's sudden departure, WMT programming director Doug Grant searched for a different personality to plug directly into Marshal J's established format. Thus, Dr. Max's avuncular world traveler character was inserted seamlessly into the existing program structure. The two-week transition was so seamless, in fact, that Marshal J's wood-paneled tack room set was modified only slightly to create Dr. Max's wood-paneled basement set.

45. Hollis, in Hi There, explains that children's shows were based on fostering local identification. Consequently, while some hosts moved to larger stations within markets and others moved geographically to parallel markets, comparatively few moved full-fledged programs across geography to larger markets. Those who successfully made such moves represent some of the genre's most renowned personalities, such as Chicago's Bill Jackson.

46. San Francisco Chronicle, 9/16/2005. These figures include San Francisco broadcast legends Bob "Captain Satellite" March, Bruce "Skipper" Sedly, and "Mayor Art" Finley.

47. Ralph Garry, For the Young Viewer: Television Programming for Children, at the Local Level (New York, 1962), 100. 


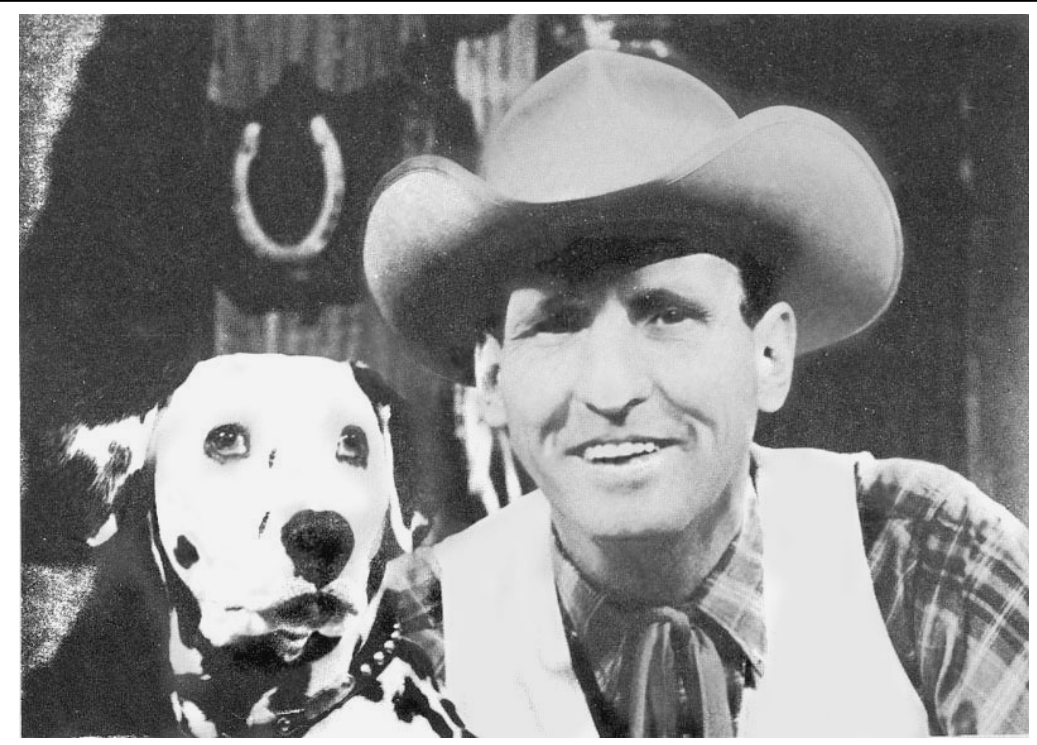

Alexander with Rowdy, his trademark companion in San Francisco. Photo courtesy of author.

From the outset, Alexander's low-key delivery and simple program format were as well received in California as they had been in Iowa. ${ }^{48}$ Gary Fissel, a member of Alexander's KPIX-TV floor crew, recalls Alexander's sudden impact: "He went straight to the top of the ratings - almost instantly. This market had never seen anything quite like what he brought to it." ${ }^{49}$

In light of Alexander's near total disappearance from public consciousness in later years, it is easy to overlook the extent and intensity of his initial popularity throughout northern California. During the peak years of the nation's television cowboy craze, between 1961 and 1964, Marshal J's image and name were pervasive throughout the Bay area. His daily program was a mainstay in the Bay area's dinner-hour television market, and advertisements featuring Alexander were displayed prominently

48. Robert Rice, telephone interview with author, 8/10/2004; Gary Fissel, telephone interview with author, 8/4/2004; Bob March, e-mail message to author, $7 / 31 / 2003$. Rice and Fissel were members of the KPIX floor crew. March is a well-remembered San Francisco children's show host from that era.

49. Fissel interview. Four other floor crew members confirmed this observation. 


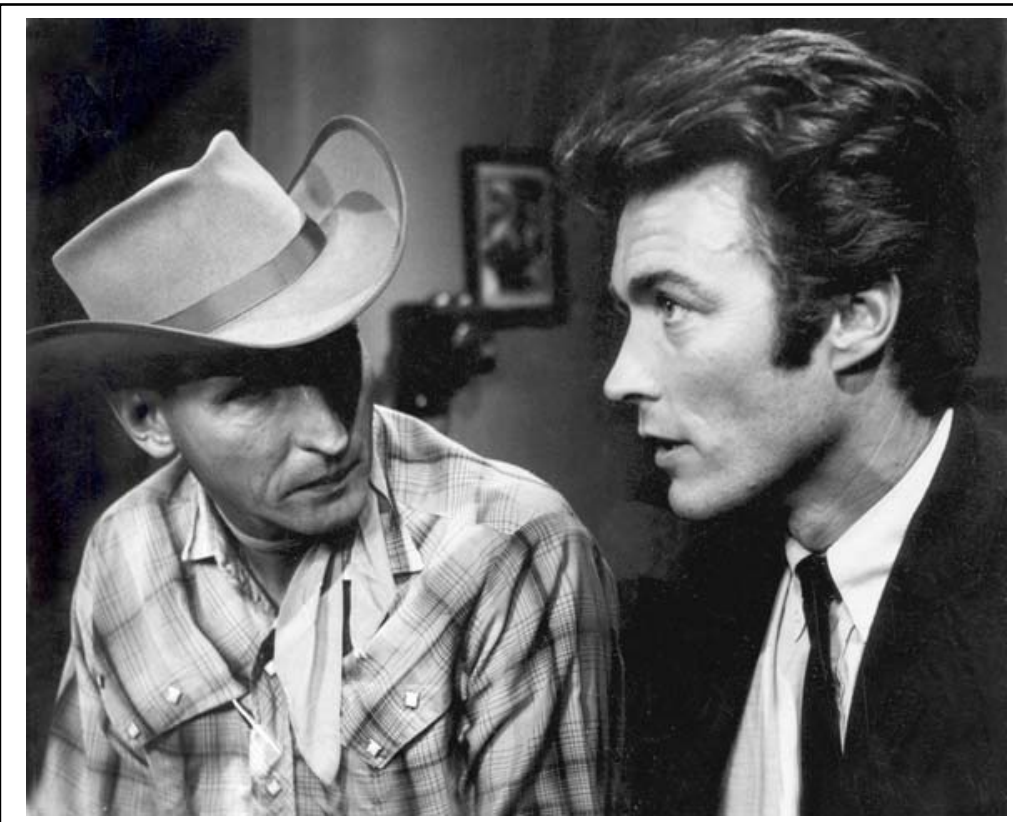

Clint Eastwood appears on KPIX with Marshal J in about 1962. Photo courtesy of Kate Yoemans.

throughout the area on billboards, on the sides of public transportation vehicles, in advertisements in professional sports programs, and in the pages of San Francisco's major newspapers. ${ }^{50}$ Alexander was equally visible on northern California's public appearance circuit; during the early 1960s, he was present at nearly every significant event in the San Francisco area that involved cowboys. And when a western star such as Gabby Hayes, Roy Rogers, or Clint Eastwood visited San Francisco during that period, they often appeared on The Marshal J Show.

The nature of Alexander's popularity and presence in California differed, however, from the daily ritual his 4 p.m. television program had represented for midwestern households. The highly competitive San Francisco broadcast market did not accommodate such total dominance and such comfortable predictability. In an effort to outflank competitors, KPIX shifted

50. Occasionally some of these advertisements still appear for sale on Webbased sites such as eBay. 
The Marshal J Show to four different timeslots in three years. ${ }^{51}$ Compared to Iowa, the San Francisco area was larger, more competitive, and more attuned to cultural trends. Adapting to these distinctions, a more polished Alexander catered to local tastes with more topical, wry humor that even middle-schoolaged children would repeat at school. ${ }^{52}$ As a result, huge audiences continued to tune in daily and flood KPIX with fan mail. ${ }^{53}$ At public appearances, Alexander was often mobbed by an equal mix of enthusiastic girls and boys ranging in age from toddlers to teenagers. Alexander relished the interaction and, as he did in Iowa, he greeted individual fans with his trademark "Hi Whitey!" "Hi Red!" or whatever cowboy nickname best addressed each child's appearance. Reflecting the intimacy he established with his viewers, he typically would fold his memorably long legs into a distinctive squat so he could address even the smallest of the children eye-to-eye. ${ }^{54}$

Former colleagues and members of KPIX floor crews, who saw their share of major celebrities pass through the studios, remember Alexander as one of the most charismatic and talented people they ever met. Fissel explains, "Jay had that rare ability to light up a room when he walked in. If you ever met him, it was an unforgettable experience." ${ }^{55}$ Consequently, KPIX management initially was thrilled with its new cowboy star and quickly signed him to an eight-year contract. In late 1961, in response to a National Association of Broadcasters (NAB) survey of children's programs across the nation, KPIX presented Alex-

51. Television stations do not document such strategies. The only consistently viable way to assess such issues in retrospect is to sift through old television listings in newspaper archives. See Ted Okuda and Jack Mulqueen, The Golden Age of Chicago Children's Television (Chicago, 2004), in which the authors discuss the rationale associated with shifting local schedules to promote ratings objectives in larger markets.

52. David Kaye, e-mail message to author, 6/20/2003. Kaye, a San Francisco fan, specifically recalls such discussions during his middle school years. Alexander's daughter Kate Yoemans confirmed that her father's act became far more polished during this period.

53. Yoemans, e-mail message. Yoemans has maintained a small family scrapbook that includes photographs of such events. Most family photographs, however, were destroyed in a 1980 fire.

54. San Francisco Examiner, 5/3/1964.

55. Fissel, interview. See also Rice, e-mail message. 


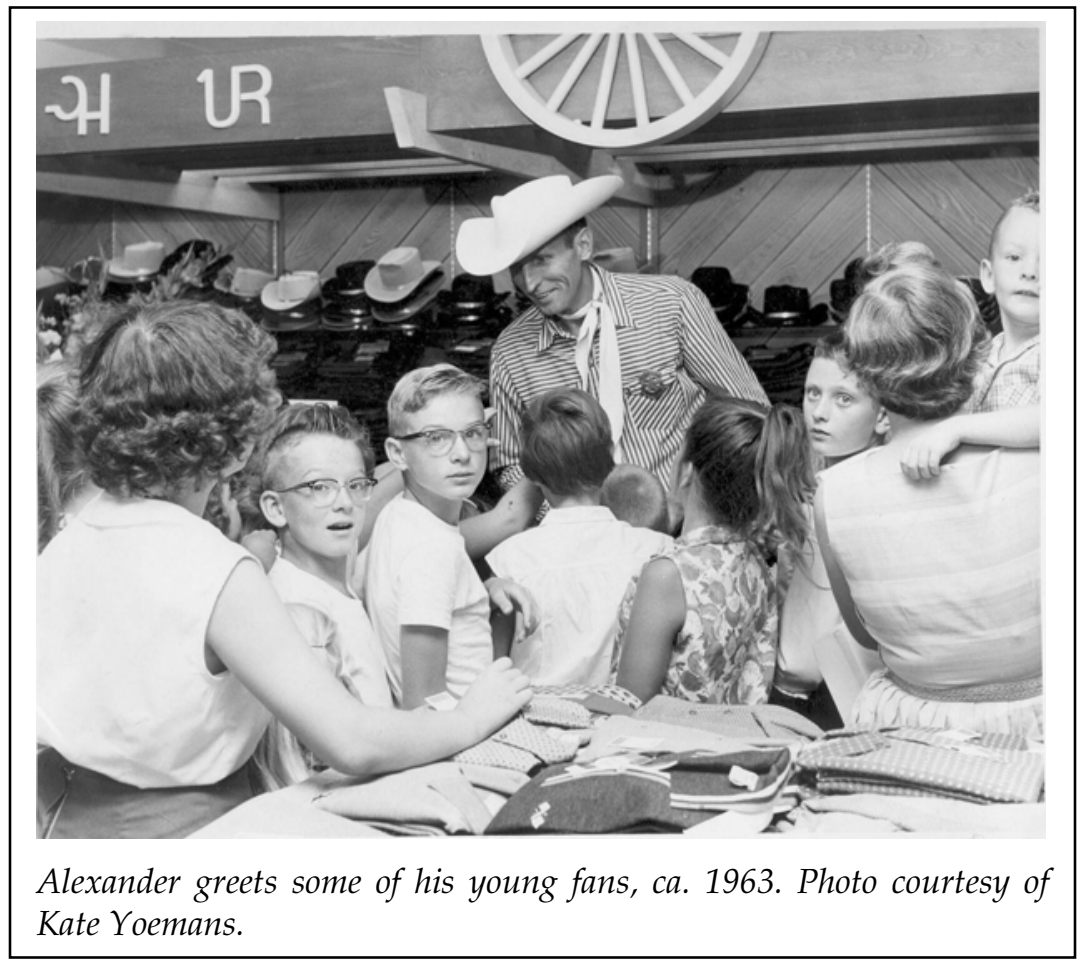

ander as an exemplar of children's television at its best. A year later, the NAB published the survey results as a book, For the Young Viewer, which highlighted Marshal J's contributions to children's television, lauding him for his efforts to "help keep alive an authentic picture of the period and region that made this country's primary contribution to folk history." ${ }^{56}$

For a while, Alexander's success, both on air and in other media ventures, seemed promising. In an effort to capitalize further on his popularity, Alexander marketed himself as a western-themed model and character actor. As an inaugural Marlboro Man model for the famous Marlboro Country cigarette campaign and as a national model for Levi's jeans, his distinctive silhouette appeared on billboards, in magazines, and in

56. Garry, For the Young Viewer, 100. The survey was conducted in response to growing criticism that the genre was over-commercialized and generally vacuous. 


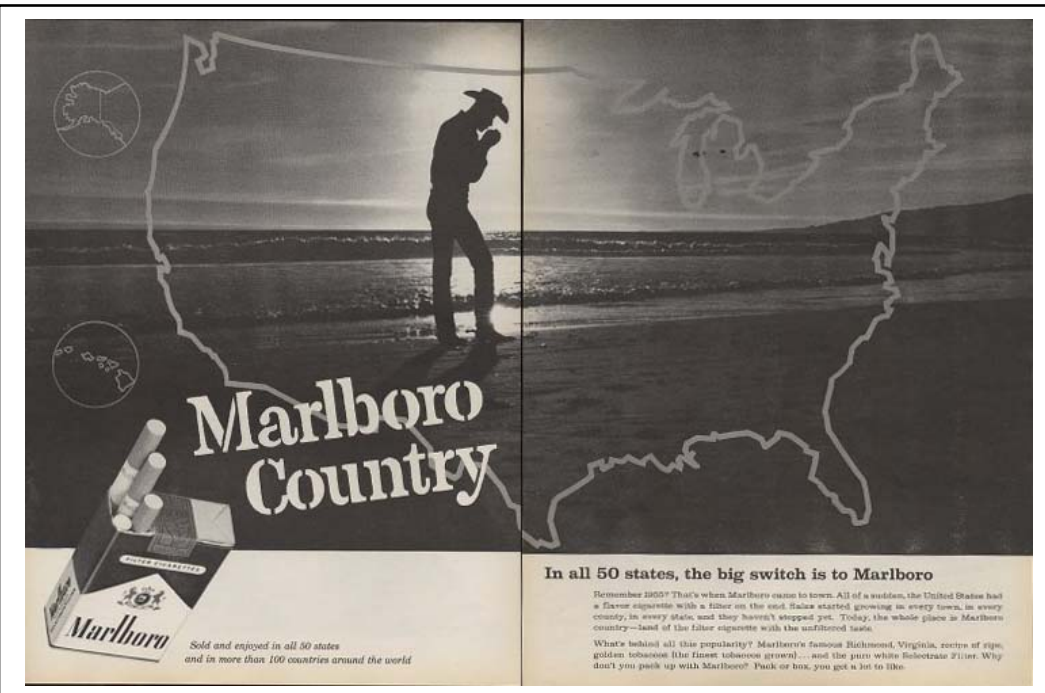

Imagine this as a full, two-page spread in the oversized Life Magazine in 1963. This double-truck advertisement represents one of the earliest national appearances of the Marlboro Country campaign. It depicts Alexander lighting up a cigarette while standing on a California beach. In all, Alexander appeared in approximately six advertisements, most of which appeared in early 1963. Life Magazine, 11/8/1962.

newspapers around the world. ${ }^{57}$ Alexander also played several small roles on prime time western classics such as Gunsmoke and alongside Dale Robertson on The Iron Horse, a shorter-lived series. $^{58}$ By May 1963, when Marshal J was toasted as grand marshal of the Bay area's world-famous Mother Lode Round-up Parade, Alexander's career was at its peak.

ALEXANDER'S SUCCESS in California proved to be short lived, however, and, as was the case in Iowa, alcohol was implicated. California colleagues recall that by late 1963 allegations of minor alcohol incidents were making some KPIX executives skittish. The bottom fell out in April 1964 when police charged Alexander with assault and battery after he scuffled with a rude

\section{Life, $11 / 8 / 1962$.}

58. San Francisco Examiner, 11/8/1978. Alexander family photographs document some of these events. The Iron Horse ran on ABC-TV from 1966 to 1968. 
waiter at an upscale restaurant in Sausalito. When news outlets prominently reported the incident, KPIX executives panicked and quickly fired Alexander, charging that the negative publicity was a breach of contract. Yet even as KPIX insulated itself by putting a "Marshal J clause" in all future contracts, Alexander's young fans publicly protested KPIX's action. ${ }^{59}$ Thus, by the summer of 1964, when Alexander was acquitted of assault charges after it became known that the waiter in question had a penchant for provoking celebrities and suing them if they retaliated, Bay area ABC affiliate KGO had resurrected The Marshal J Show in its morning lineup. ${ }^{60}$

After spending a decade helping children unwind after school, however, Alexander, with his laid-back style, was less suited for the 7:30 a.m. weekday time slot. Furthermore, instead of featuring the top-drawer theatrical cartoons that had been a Marshal J centerpiece since 1957, KGO saddled Alexander with poor quality made-for-TV cartoons. ${ }^{61}$ An ill-conceived mountainman sidekick not only failed to compensate for the inferior cartoons, but some fans even recall that the sidekick's presence undermined the intimacy Alexander had cultivated with his audience. Although The Marshal J Show remained reasonably popular, by most accounts the magic was fading. As the 1960s progressed, television cowboys drifted out of style, and stations increasingly replaced costly in-studio programming with less expensive syndication packages. By 1967, as the counterculture and social turmoil swept cross the San Francisco Bay area, Marshal $\mathrm{J}$ had become an anachronism. As an early reflector of a national trend that within approximately five years eliminated most

59. San Francisco Examiner, 5/3/1964. San Francisco newspapers ran several articles addressing the incident and Alexander's firing. Ron Magers, e-mail to author, 8/7/2004. Magers, a noted Chicago newscaster who joined the KPIX staff shortly after Alexander retired from broadcasting, recalls signing the "Marshal J clause" upon joining KPIX.

60. San Francisco Examiner, 11/8/1978; Rice, e-mail message.

61. Hollis, Hi There, discusses the emergence of quickly produced made-fortelevision cartoons. Of all these lower-quality cartoons, few were inferior to the rock-bottom Clutch Cargo and Space Angel series Marshal J featured on KGO. These cartoons used a bizarre animation technique known as synchrovox, which involved superimposing actors' moving mouths over the cartoon images. Often, the moving mouths were the only motion in the otherwise static cartoons. 
of the hosted children's show genre, KGO officials explained to Alexander that his program was no longer cost effective. ${ }^{62}$ Thus, in April 1967 Alexander quietly left broadcast television forever.

Without the creative outlet television afforded, Alexander's post-broadcasting years proved to be a long series of personal and professional setbacks that hit a nadir in March 1982 when his wife of 35 years died of cancer. ${ }^{63}$ By then besieged with assorted chronic health problems himself, Alexander died of natural causes only ten months later. To the end, he lamented the passing of an era in broadcasting and popular culture that, to him, once seemed as if it would last forever. In November 1978, during what proved to be his final public interview, Alexander ruefully told a San Francisco Examiner reporter that television "wasn't a job for me, it was, well, a love. I read one time that someone said, 'When it ceases to be fun, I'll get out of it.' Well, it never ceased to be fun for me. I got out only because of trends and economics that squeezed me out." ${ }^{64}$

When Alexander died four years later at age 61, some pundits considered him so irrelevant that the Cedar Rapids Gazette acknowledged his death and career with an 83-word obituary:

Jay "Marshal J" Alexander, 60, of San Mateo, Calif., formerly of Cedar Rapids died Tuesday at San Diego, Calif. following a long illness. He was host of a children's show called "The Marshal J Show" on WMT-TV from March 1954 until late 1960, when he moved to California. ${ }^{65}$

In California, the Bay area's most dominant newspaper, the San Francisco Chronicle, ignored the story altogether. ${ }^{66}$

62. Neil Hickey, "Skipper Chuck and Buckskin Bill Are Not Feeling Very Jolly," TV Guide, 6/2/1973. Yoemans confirmed this account.

63. During this period Alexander's most notable job involved calling whale shows at a Bay area aquatic park. For a short time he also sold automobiles, and he also held a short-term public relations position. In 1980 he briefly returned to cable television to provide color commentary for BMX motocross races.

64. San Francisco Examiner, 11/8/1978.

65. Cedar Rapids Gazette, 1/19/1983. The obituary incorrectly lists Alexander's age as 60 rather than 61 .

66. In contrast, the then fading San Francisco Examiner featured a nine-paragraph account on its obituary page based heavily on the interview for the 1978 Examiner article cited earlier. San Francisco Examiner, 1/21/1983. 
A DECADE AFTER ALEXANDER'S DEATH, as part of efforts to commemorate the fortieth anniversary of WMT-TV (which changed its call letters to KGAN in 1981), veteran KGAN reporter Cary J. Hahn sought to produce a retrospective segment on Marshal J's impact on the station. However, despite joining with amateur broadcast historians and chasing scores of leads to California and beyond, Hahn was able to find only approximately six still photographs and a couple of promotional items - all of which could fit easily into a small manila envelope. As he explains, like so much of the "here today, gone today" era of live local television, almost nothing, other than memories, remained of Marshal J. Closer examination, however, reveals that even as much of Alexander's world indeed has disappeared, he has maintained a revealing presence within the domain of collective memory in both Iowa and California. Furthermore, as discoveries in the course of the research for this article have revealed, collective memories have proved less ephemeral and more fecund than Hahn's experience might suggest. In fact, oral histories collected from former colleagues and fans indicate the extent to which Marshal J has been remembered with particular ambivalence in both Iowa and California.

The disposable nature of Alexander's genre and its attendant lack of documentation carved out few formal spaces for articulating memories of Marshal J with one exception: urban legends. During his time in Iowa, Alexander's conspicuous problems with alcohol fueled a good deal of gossip among viewers across the region. After he left for California, much of that gossip was preserved in Iowa urban legends, some of which still persist. Although some Marshal J urban legends represent reasonably accurate accounts of actual events, others are wildly inaccurate or totally fictitious. ${ }^{67}$ Urban legends do offer

67. In some respects, Marshal J urban legends represent a genre of their own in eastern Iowa. Many involve the very real incidents on the weathercast, The Marshal J Show, and the leg-shooting incident. Even though relatively few living viewers witnessed these events, many respondents will spontaneously recite variants or composites of these genuine happenings. The most common of the fictitious legends takes the form of a Marshal J version of the age-old, and thoroughly discredited, "That oughta hold the little bastards" myth. In many tellings, this fictitious miscue led to his equally fictitious firing at WMT. California respondents occasionally cite the latter fallacious legend; they also cite various exaggerated accounts of the 1964 restaurant incident. 
insights into cultural values and perceptions, but to the extent that such narratives are inaccurate or lack perspective, they have undermined Iowa's historical record in several respects. Most notably, they have been partially responsible for marginalizing Alexander as a legitimate historical subject, and they also have perpetuated widely believed historical inaccuracies. The most pervasive canard in this respect, one that has undermined the historical record for nearly five decades, incorrectly claims that WMT summarily fired Alexander, purportedly for the bowand-arrow stringing incident. ${ }^{68}$

As oral histories move beyond the urban legends, however, it becomes clear that, among certain age groups, Marshal $\mathrm{J}$ is remembered as a distinctive cultural phenomenon. These accounts, many of which represent enthusiastic responses to openended inquiries placed in newspapers and on Internet sites, portray the affective nature of such early television rituals and popular culture trends. A repeated theme emerges from these responses: Former viewers give a clear sense that Marshal J was not merely a program that they watched each day, but the 1950s icon also represents a vital part of who they were during that halcyon era.

Such memories generally fall into two categories: those informed by personal knowledge of or interaction with Alexander, and those based on experience watching The Marshal J Show and participating in the daily rituals it represented. Those who knew or met Alexander offer anecdotes that help reconstruct his largerthan-life presence. Examples of these memories include accounts of enthralled children watching the cowboy gallop across a cornfield from his Cedar Rapids home to a nearby elementary school, dismount, and play unselfconsciously with schoolchildren during recess. Some fans fondly remember waiting amid

68. Multiple sources, both family friends and some former WMT colleagues, assert that this claim is false. As David Grant notes, "Just for the record Jay was not dismissed. ... At least his boss (my father) told me that he left to go to a much better job on the coast." A variety of documented events appear to confirm this account. An article in the Cedar Rapids Gazette, 1/18/1961, portrays a well-planned farewell social gathering the Hulls hosted in honor of the Alexanders. Alexander also made a well-advertised and somewhat triumphant return to Cedar Rapids in August 1962. Cedar Rapids Gazette, 8/5/1962. Furthermore, Alexander continued to make personal appearances in Cedar Rapids well after his final appearance on WMT. Cedar Rapids Gazette, 1/15/1961. 
throngs of children to greet Alexander as he arrived by helicopter at various public appearances; one remembers the thrill of furtively touching the bullets on Marshal J's gun belt as he walked by. Several of those who remember watching Marshal J on television recall a daily ritual that consisted of unwinding after school by changing from school clothes into western gear, then settling in to watch Marshal J. For children in the Bay area near the end of his career, the show became a morning ritual. Film star Tom Hanks explained to a worldwide television audience in 2008 how television rituals structured daily life during the 1950s and '60s: "Time is not told by watches or clocks but by whatever is on TV. After Marshal J and the cartoons you go to school." ${ }^{69}$

Contrary to what seemed to be the case when Alexander died in 1983, material artifacts of his career and social presence did not totally disappear. As it turns out, a good deal of tangible history related to Marshal J was preserved for five decades in closets, drawers, basements, and attics of his former viewers. Even more so than oral histories, these personal collections, all of which were assembled as individual acts separate from any social network or monetary concerns, attest to very personalized perceptions of value. Several fans, for example, provided historically revealing promotional material, including various photo composites and a thought-to-be-lost 45-rpm record of Marshal J telling stories. One woman forwarded a ruler that Marshal $\mathrm{J}$ had signed at a promotional appearance 50 years ago. She offered a poignant account of how she waited patiently behind hundreds of children for the chance to meet her television hero, how she prized the ruler throughout her grade-school years, and how she kept it for five decades. ${ }^{70}$ Even more poignant, a mother, now in her late seventies, sent photographs of Alexander providing a special show to her terminally ill fouryear-old son, who soon thereafter would die of leukemia. "That

69. Tom Hanks, "Rock and Roll Hall of Fame Induction Remarks: The Dave Clark Five," speech presented at the Twenty-third Annual Rock and Roll Hall of Fame Induction Ceremony, Waldorf Astoria Hotel, New York, 3/10/2008. Hanks, who grew up in the San Francisco Bay area, refers to Alexander's tenure on KGO-TV in San Francisco from 1964 to 1967.

70. Kathy Warden, correspondence with author, 6/14/2005. 


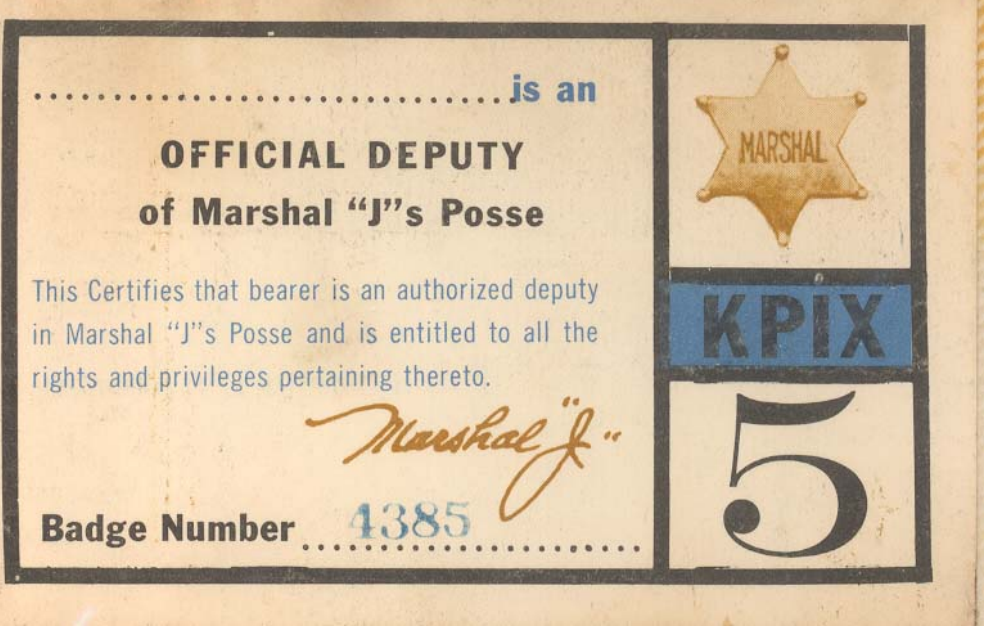

This certificate is one of the artifacts kept by fans of Marshal J for the more than 50 years since his program captured the hearts of his viewers. Courtesy Robert Rice.

was one of the best days our David could have had. He so enjoyed the things Marshal J did for him. . . . I will never forget the kindness shown to a little boy who did not have too long to live." ${ }^{71}$

As a reflector of collective memory that has had little formal outlet, the act of individually saving particular local television artifacts gives historians a better sense of how viewers experienced particular broadcast rituals and how they valued those experiences. In the case of Alexander and other poorly documented local broadcasting icons, such artifacts represent a useful tool for documenting the lost content of such historical mass media rituals and understanding their affective impact on viewers in time and over time. Ironically, this reality represents perhaps the only aspect of his long-term social influence that did not escape Jay Alexander himself.

Until the end of his life, the long-retired broadcaster remained astonished and gratified each time a former viewer (in these instances in California) recognized him and produced a

71. Patricia Nievas, correspondence with author, 11/13/2005. 
treasured Marshal J promotional item that was accompanied by nostalgic stories about a bygone era. During his final public interview, Alexander described such an encounter and mused, "Imagine that, he must have kept that badge in a drawer or something for fifteen years." ${ }^{72}$ Decades later, the spontaneous emergence of similar artifacts reflects the nature and significance of the broader issues Alexander's story represents. In these respects, a 50-year-old autographed ruler can measure more than inches and feet; it also can help historians gauge a sense of memory, a sense of ritual, and a sense of a past that otherwise would have escaped the net of historical study. 